\title{
DIGITAL TRANSFORMATION AND ITS INFLUENCE ON CHANGING THE MARKETING ORIENTATION OF BUSINESS STRUCTURES AND CONSUMER BEHAVIOUR
}

\author{
Yuliia Radzikhovska'
}

\begin{abstract}
Purpose of scientific research. The purpose of the research is to present the features of digital transformation and its impact on changing marketing orientation of business structures and consumer behaviour in particular, and to determine main value in digital economy, which is the customer, as well as to indicate marketing initiatives to enhance consumer behaviour $Y, Z$. The object of scientific research. The object of the scientific research is the process of digital transformation of business structures and changes in marketing orientation, which can be traced and understanding consumer behaviour in terms of generations of baby boomers, X, Y, Z. Methodology. Based on dialectical, systemic and matrix methods, the influence of digital transformation on consumer preferences and behaviour, as well as the change in marketing orientation, which determines new quality and format of business structures, has been studied. A comparative analysis of the types of generations of consumers that determine the further content of marketing initiatives in business is used. The result of the article. Marketing initiatives to enhance consumer behaviour are presented, taking into account the preferences and behaviour of online consumers. It is determined that the advantages of digital transformation for business structures are the improvement of the customer base, increased flexibility and acceleration of business processes, innovative opportunities for business development. Practical implications. Digital transformation of business structures and the changes traced in them in three stages are revealed, namely: automation (transfer of business processes to electronic systems for storage and exchange of data in the existing form and in the way in which they work at the enterprise); digitalization (optimization of individual business processes with adaptation to tools and technologies of digital economy); digital transformation (involves a qualitative change of the entire business model of the enterprise, starting from the strategy and ending with the digitalization of all (management, core and supporting) business processes). Marketing initiatives influencing values, priorities, ways of communication of different generations of consumers are specified. Value/originality. Matrix structure of preferences and behaviour as online consumers, representatives of generations of baby boomers, $X, Y, Z$ in terms of priorities in online shopping, frequent purchases, reasons for buying online, reasons for dissatisfaction with purchases, additional information is proposed. Key directions of strategic transformations are defined, among which there are customer service, values, work with data, introduction of innovations.
\end{abstract}

Key words: digital transformation, marketing orientation, business structures, consumer behaviour, generations of people, millennials, buzzers.

JEL Classification: O32, G14, M10, D11

\section{Introduction}

Digitalization processes are increasingly influencing the socio-economic development of countries around the world, changing approaches to solving problems at different levels and in different spheres of life. First of all, the changes affected the processes of generation, transmission, storage, management and analysis of

Corresponding author:

${ }^{1}$ Educational-Scientific Institute of Economics and Law

of Bohdan Khmelnytskyi National University at Cherkasy, Ukraine

E-mail: k23k@ukr.net

ORCID: https://orcid.org/0000-0002-6691-3182

ResearcherID: https://publons.com/researcher/4355116/radzikhovska-yuliia/ information, which makes the latter an important production resource. This, in turn, changes the paradigm of society, reducing the dependence of economic growth on the country's extensive factors, including natural resources, working population, fixed capital, etc., which are characterized by the greatest entropy.

The development of information technology becomes a key condition for ensuring the competi- 
tiveness of both individual enterprises and countries as a whole, leading to the restructuring of all economic and production processes, improving the quality and reducing the cost of goods and services. Digitalization is creating fundamentally new opportunities to improve well-being and address pressing social issues from health to education and the environment.

The beginning of 2020s has shown that the trajectory of e-commerce development and marketing orientation of business structures has changed significantly. Until recently, those who worked in the field of online commerce focused primarily on the intentions of buyers, tried to track the interest of online visitors and use it to their advantage.

Thus, marketing orientation of e-commerce entities is aimed at the desire to "catch" the existing demand, which can be met in the most convenient way for buyer and the least expensive for the seller. Earlier in the online store, buyer has been shown the product he or she wants to buy. It is easy to do: to track goods that buyer puts in the e-cart. However, not all products left in the basket meet the wishes of the buyer, and not all of them are bought.

As a result, the business philosophy changes under the influence of digitalization, as well as the behaviour of e-commerce participants. It is not enough to simply track existing intentions; we need to think more broadly - how to create a completely new demand that will contribute to further growth. It is important that the product itself finds buyers in e-commerce.

This new approach to e-commerce is called discovery commerce. Its essence is that successful in the market are those e-commerce entities that seek not only to meet customer demand, but also have the desire to create demand and inspire people to get acquainted with a new product. It is assumed that discovery commerce includes attempts to predict people's desires through the peculiarities of their behaviour, active use of modern tools to demonstrate to customers a relevant offer, seamless experience for all e-commerce participants, creating a secure environment that ensures data preservation (Facebook, 2021).

However, the effectiveness of new e-commerce concept largely depends on who it targets. This means that it is not possible in the course of digital transformation to ignore the style of behaviour of different generations of buyers in global e-commerce market. We are well aware of generations of baby boomers, X, Y, Z. What makes each generation special? What are the effects of digital transformation observed today on the change of marketing strategy of business structures? What will be the behaviour of consumers during digital transformation? We will try to answer all these questions during the disclosure of the content of this article.

\section{Literature review}

The issue of digital transformation of business, the formation of digital entrepreneurship is just beginning to attract the attention of foreign and domestic researchers, including Isaacson V., Azzam M., Sami N., Khalil T., Klaus S., Shantarenkova M. Based on the analysis of experience, it is established that the concept of digital transformation has three main advantages relevant to any type of business: improving the efficiency of existing infrastructure; emergence of qualitatively new business models; increase revenue or reduce costs in existing business models.

These results are presented in scientific works and articles by Andrusiak N., Burlakova I., Kradich V., Chmeruk G., Grybanova Yu., Rudenko M., Konyk L., Prokhorova A., Makarova A., Nechepurenko M., Ouchi W., Pogorelova Yu., Pisano G., Teece D., Shuen A., Tapscott D., Toralo M., Chernykh E., Chechina $\mathrm{O}$.

Among the domestic researchers engaged in the disclosure of the content of the preferences of different generations in the digital economy there can be mentioned Gomonova D., Goloborodko O., Kraus N., Kraus K., Marchenko O., Manzhura O. The analysis of these recent studies has shown the need for a comprehensive approach to substantiate features of digital transformation and identified the impact of changes in marketing policy of enterprises, taking into account the tastes and preferences of today's generations.

The purpose of the paper is to present the features of digital transformation and its impact on changing the marketing orientation of business structures and consumer behaviour, in particular, which has all chances to become a decisive step in accelerating the launch of the digital strategy of economic development of Ukraine and determining the main value in the digital economy, which is the customer and marketing initiatives to enhance consumer behaviour of generations of baby boomers, X, Y, Z.

Among the tasks set in the article there are the following: to reveal digital transformation of business structures through the prism of value chain; to present digital transformation of business structures and changes that can be traced; to provide an author's vision of marketing initiatives to enhance the consumer behaviour of generations of baby boomers, $\mathrm{X}, \mathrm{Y}, \mathrm{Z}$; to indicate the benefits of digital transformation for business structures and change of marketing orientation; to identify and reveal the content of preferences and behaviour as online consumers, representatives of generations of baby boomers, X, Y, Z.

\section{Digital transformation of business structures}

The transformative power of "digital" technologies allows to change traditional business models, marketing policy, production chains and causes 
the emergence of new products and innovations. Digitalization brings the sphere of production to a new level, forcing enterprises to make digital transformation the main task of development strategy. Based on the analysis of literature sources, it is established that digital transformation of business structures is the introduction of modern technologies into their business processes. This approach implies not only the installation of modern hardware or software, but also fundamental changes in approaches to management, marketing orientation, corporate culture, external communications. As a result, the productivity of each employee and the level of customer satisfaction increase, and the company gains a reputation for progressive and modern. The latest digital technologies of "digitalization" process lead to innovative transformations in all spheres of enterprise activity and encourage the creation of new business models.

The owner can be both the head and the executor of all stages of work in business structure. Main value in digital economy is the customer - who becomes main in the process of economic activity, because without it there is no point in it itself. Customer chooses product based on advice, personal experience and advertising; seller does not have the opportunity to personally contact the buyer. At the same time, advertising still has its weight, only it is already Internet advertising, Internet fashion, Internet friends, Internet hobbies, etc. (Nechepurenko, 2006).

A characteristic feature of digital economy is its connection with the on-demand economy, which involves not selling goods and services, but gaining access to them at the very moment when it is needed.
Orders are received online and executed offline. The advantages of on-demand economics are: high speed of obtaining the required service or product; reducing their cost to the end user by reducing the number of intermediaries; simplifying the access of suppliers of goods and services to users. Digital transformation is accompanied by changes in economic business processes: from the robotization of the production of goods (goods and services) for mass consumption to new industries for the creation of goods with individual characteristics for each consumer.

In modern business in Ukraine there are widely used technologies of information retrieval systems on the Internet, advertising and sale of goods on the Internet, electronic payments, electronic tenders, electronic card payments (including payroll), automated systems of salary accounting, accounting and reporting processes, electronic systems of protection and fire safety, electronic systems of information collection of control and measuring devices, mobile and selector communication, etc.

The concept of digital transformation has three main advantages relevant to any type of business: increase the efficiency of the existing infrastructure; emergence of qualitatively new business models; increase revenue or reduce costs in existing business models.

Digital transformation of business structures goes far beyond the ICT industry, it has an impact on the entire value chain. In particular, we can consider three areas presented in Table 1, in which new digital technologies can be used (Chechin, 2014).

The gradual process of digital transformation of business structures, in our opinion, can be represented in the form of 3 stages, which are presented in Table 2.

Table 1

Digital transformation of business structures through the prism of the value chain

\begin{tabular}{|l|l|}
\hline \multicolumn{1}{|c|}{ Directions } & \multicolumn{1}{|c|}{ General characteristics } \\
\hline Business models & digital transformation makes it possible to develop completely new forms of creating and obtaining value \\
\hline Customer search & $\begin{array}{l}\text { firms can use digital information and social networks to attract their customers in new ways. For example, they can } \\
\text { create digital user communities to add value }\end{array}$ \\
\hline Operating processes & digital technologies make it possible to achieve great results in operating activities at all stages of the value chain \\
\hline
\end{tabular}

Source: development of author

Table 2

Digital transformation of business structures and traceable change

\begin{tabular}{|c|c|l|}
\hline Stages & The name of the stage & \multicolumn{1}{|c|}{ The content of the process of digital transformation of business structures } \\
\hline 1 stage & Automation & $\begin{array}{l}\text { it is the transfer of business processes to electronic systems for storage and exchange of data in the } \\
\text { existing form and in the way in which they operate in the enterprise }\end{array}$ \\
\hline 2 stage & Digitalization & $\begin{array}{l}\text { the stage at which there is an optimization of separate business processes with adaptation to tools and } \\
\text { technologies of digital economy. Digitalization reduces the number of steps required to perform a } \\
\text { specific task, reduces the amount of work with documents and the impact of human factor, avoiding } \\
\text { mistakes }\end{array}$ \\
\hline 3 stage & Digital transformation & $\begin{array}{l}\text { provides a qualitative change in the entire business model of the enterprise, from strategy to } \\
\text { digitalization of all (managerial, core and supporting) business processes }\end{array}$ \\
\hline
\end{tabular}

Source: development of author 


\section{Digital transformation and marketing orientation of business structures}

The basics of the benefits of digital transformation for business structures and changes in marketing orientation are presented in Figure 1.

It has already happened that in the context of generations today it is possible to clearly trace the differences in priorities, values, traditions, stereotypes and preferences of different age groups of consumers, which determines the change in the marketing orientation of business structures. Therefore, it is not surprising that in order to consolidate their leading positions in the market, modern business structures compete not only for market share or consumer attention, but also fight fiercely for supremacy in the use of the latest marketing tools. However, the choice of the latter nowadays largely depends on the target audience, which focuses on the business entity, and this is a certain age group of consumers.

In the last few years, generation $\mathrm{Z}$ has become increasingly important in global market, as its representatives not only strengthen their purchasing power (purchasing power and financial stability). It is buzzers today who set market trends that quickly become "viral", move into the genre of "challenge" and are easily picked up by predecessor generations - $\mathrm{X}$ and Y. Generations of baby boomers, as their respectable age today is 57-75 years, are rarely subjected to "waves of change", but often experiment and strengthen digital world to strengthen ties with younger generations.

In this context, the choice of the most acceptable and effective marketing tools for business activities will largely depend on the generation to which target audience belongs. This becomes critical during global spread of the COVID-19 pandemic, which significantly shifts the focus of business development and "transferred" many business processes to the world of Internet and virtual reality. Undoubtedly, the isolation of countries (closing borders, declining transport traffic, declining tourism, rising unemployment, declining purchasing power) during the spread of the COVID-19 pandemic, somewhat "slowed down" the dynamics of globalization and integration, intensified competition, and those win who restructure their marketing and business processes and adapt to new conditions.

\section{Marketing initiatives to enhance the consumer behaviour}

Table 3 presents the generations marked by somewhat "blurred", "conditional" time boundaries between them, due primarily to the different and unique socio-cultural, economic and educational circumstances in different countries around the world that influenced their formation. Therefore, we can state that the only universally recognized classification of generations of people still does not exist - the boundaries are shifted a few years forward or backward, and this is normal.

When we talk today about increasing customer loyalty, especially those who are focused on the online market, then of course we are talking about generations of people who are active online users, and in accordance with modern digital technologies, they are "to YOU". The reason for this is that such generations of people have grown (and this is primarily generation $\mathrm{Z}$ ) and formed as individuals (generation B) during the spread of high-speed Internet in the early 21 st century, the emergence of smartphones in 2010. These factors have become main driver of such a rapid penetration

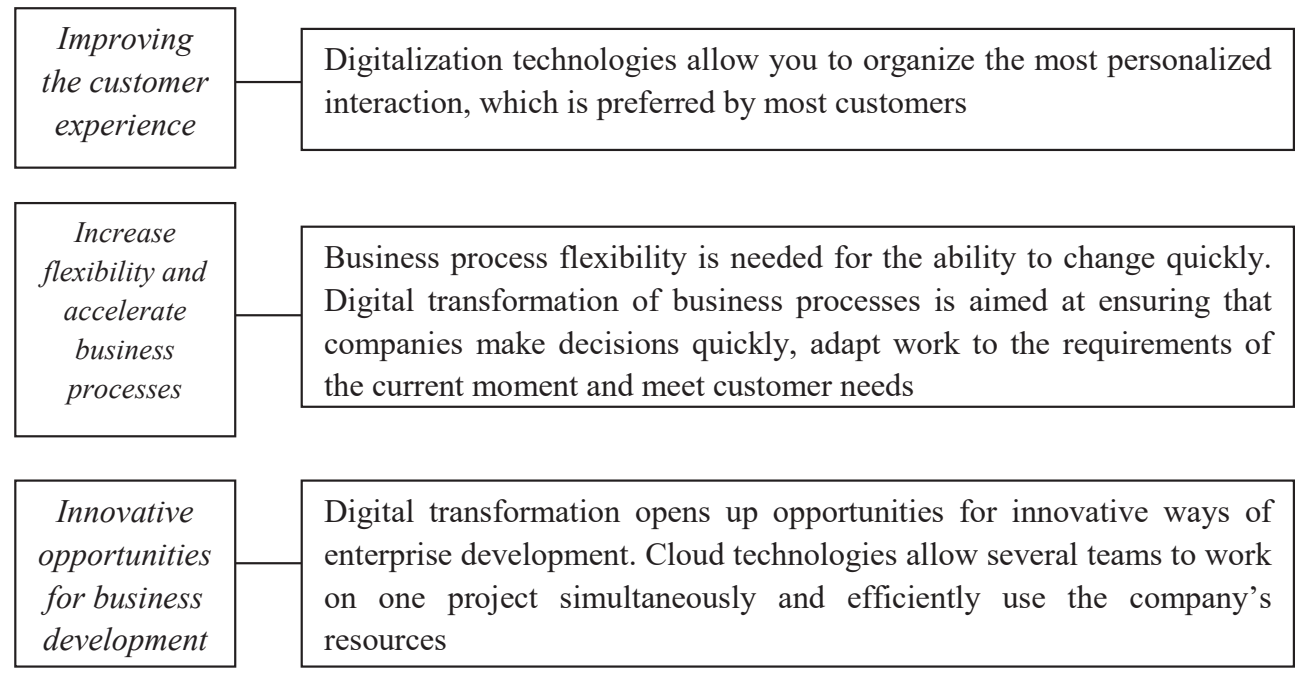

Figure 1. Advantages of digital transformation for business structures and change of marketing orientation Source: development of author 
Table 3

Marketing initiatives to enhance the consumer behaviour of generations of baby boomers, X, Y, Z

\begin{tabular}{|c|c|c|c|c|}
\hline & \multicolumn{4}{|c|}{ Generation type } \\
\hline & $\begin{array}{l}\text { baby boomers } \\
(1946-1964)\end{array}$ & $\begin{array}{c}X \\
(1965-1979 / 80)\end{array}$ & $\begin{array}{c}\text { Y, millennials } \\
(1981-1994 / 6)\end{array}$ & $\begin{array}{c}\text { Z, buzzers } \\
(1997-2012 / 15)\end{array}$ \\
\hline 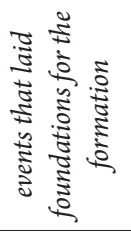 & $\begin{array}{l}\text { optimism after World War } \\
\text { II, the Cold War, hippies in } \\
\text { fashion }\end{array}$ & $\begin{array}{l}\text { the end of Cold War, the } \\
\text { popularity of rock music, } \\
\text { the spread of personal } \\
\text { computers, the development } \\
\text { of information technology }\end{array}$ & $\begin{array}{l}\text { Great Recession, the } \\
\text { technological "explosion" of } \\
\text { Internet and social media, } \\
\text { the spread of postmodern } \\
\text { culture, the collapse of the } \\
\text { USSR }\end{array}$ & $\begin{array}{l}\text { smartphones, tablets, social } \\
\text { media and networks see their } \\
\text { parents' financial difficulties } \\
\quad(\text { generation X) }\end{array}$ \\
\hline 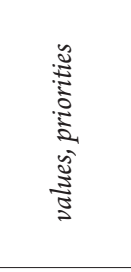 & $\begin{array}{l}\text { everything is possible, } \\
\text { equal opportunities for all, } \\
\text { personal satisfaction, work } \\
\text { makes a person noble, family } \\
\text { always comes first }\end{array}$ & $\begin{array}{l}\text { independence, pragmatism, } \\
\text { entrepreneurship, the } \\
\text { tendency to rely solely } \\
\text { on their own strength, } \\
\text { unwillingness to be as } \\
\text { dependent on work as their } \\
\text { parents }\end{array}$ & $\begin{array}{l}\text { global thinking, tolerance, } \\
\text { focus on today, desire for } \\
\text { self-development, balance } \\
\text { between work and life } \\
\text { outside work }\end{array}$ & $\begin{array}{l}\text { clip perception, graphic } \\
\text { visualization, teamwork, creating } \\
\text { something new, realism, focusing } \\
\text { on the future }\end{array}$ \\
\hline 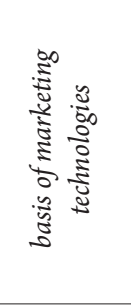 & $\begin{array}{l}\text { formed as individuals and } \\
\text { acquired their first profession } \\
\text { without the Internet; do } \\
\text { not trust advertising on the } \\
\text { Internet; buy on the advice } \\
\text { of relatives and friends; the } \\
\text { vast majority do not perceive } \\
\text { information by ear }\end{array}$ & $\begin{array}{l}\text { they know the world without } \\
\text { the Internet well because } \\
\text { they were born in it; most } \\
\text { understand modern ICT, use } \\
\text { them in work and life; spend } \\
\text { a lot of time online }\end{array}$ & $\begin{array}{l}\text { symbiosis of civil and } \\
\text { social responsibility with } \\
\text { skepticism; life here and } \\
\text { now; sense of satisfaction } \\
\text { with the present; choose } \\
\text { an interesting (and even } \\
\text { low-paid) job, rather than } \\
\text { promising for career growth }\end{array}$ & $\begin{array}{l}\text { poorly perceive text messages, } \\
\text { prefer photo and video formats, } \\
\text { voice messages; use hi-tech } \\
\text { technologies that determine their } \\
\text { future professional orientation; } \\
\text { set trends that are fast becoming } \\
\text { popular }\end{array}$ \\
\hline 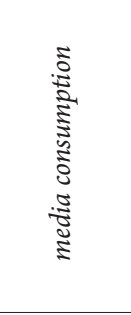 & $\begin{array}{l}\text { consumers of traditional } \\
\text { media (television, radio, } \\
\text { magazines, newspapers); } \\
90 \% \text { have a Facebook } \\
\text { account; use technology to } \\
\text { stay in touch with family and } \\
\text { friends }\end{array}$ & $\begin{array}{c}\text { read newspapers, magazines, } \\
\text { listen to the radio and watch } \\
\text { TV; digitally savvy and } \\
\text { spend about } 7 \text { hours a week } \\
\text { on Facebook (highest among } \\
\text { generations) }\end{array}$ & $\begin{array}{l}95 \% \text { watch TV, but Netflix } \\
\text { removes traditional } \\
\text { television; use of network } \\
\text { services and mobile devices, } \\
\text { but } 32 \% \text { still buy through } \\
\text { a computer; have multiple } \\
\text { social media accounts }\end{array}$ & $\begin{array}{l}\text { the average buzzer received } \\
\text { his or her first mobile phone } \\
\text { at the age of 10.3; grew up in a } \\
\text { hyperconnected world, and a } \\
\text { smartphone is the best way to } \\
\text { communicate; on average spend } \\
3 \text { hours a day with a mobile } \\
\text { device }\end{array}$ \\
\hline 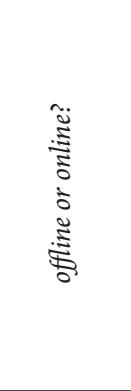 & $\begin{array}{l}\text { buy offline, because shopping } \\
\text { for them is a holiday and a } \\
\text { tradition that does not waste } \\
\text { time; before buying they } \\
\text { prefer to test, taste, try on, } \\
\text { etc.; operate on the principle } \\
\text { of "measure ten times, cut } \\
\text { once" }\end{array}$ & $\begin{array}{l}\text { prefer offline stores and } \\
\text { banks; trust more traditional, } \\
\text { "live" advertising; to "be in } \\
\text { trend" actively master online } \\
\text { shopping; choose online } \\
\text { platforms where you can buy } \\
\text { everything at once; being } \\
\text { online value their time }\end{array}$ & $\begin{array}{l}\text { have gone from online } \\
\text { games to the Internet of } \\
\text { Things; are characterized } \\
\text { by information literacy } \\
\text { and caution; search for the } \\
\text { necessary information in } \\
\text { Internet sources; prefer } \\
\text { direct advertising and } \\
\text { advertising that does not sell, } \\
\text { but entertains }\end{array}$ & $\begin{array}{l}\text { for them, the opinion of their } \\
\text { peers, experts and bloggers is } \\
\text { more important than the name of } \\
\text { company; most of their lives are } \\
\text { spent online, so Instagram and } \\
\text { TikTok are main source where } \\
\text { they "consume" advertising } \\
\text { about goods/services; they like } \\
\text { to act as advertisers, bloggers and } \\
\text { experts, giving advice to others }\end{array}$ \\
\hline 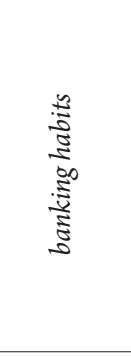 & $\begin{array}{l}\text { visit the bank for } \\
\text { transactions; use mainly } \\
\text { cash; Internet banking is used } \\
\text { with distrust and is forced in } \\
\text { extreme cases; buy today - } \\
\text { pay tomorrow }\end{array}$ & $\begin{array}{l}\text { digitally "savvy", so conduct } \\
\text { certain financial transactions } \\
\text { on the Internet, but still } \\
\text { prefer to make transactions } \\
\text { in banks; conservative in } \\
\text { financial matters; believe } \\
\text { that banking is a personal } \\
\text { business and demonstrate } \\
\text { brand loyalty }\end{array}$ & $\begin{array}{l}\text { prefer to buy goods first } \\
\text { and have no patience for } \\
\text { poor service; trust brands } \\
\text { with a great history (Apple, } \\
\text { Google); looking for digital } \\
\text { tools to help manage your } \\
\text { debt; earn to spend }\end{array}$ & $\begin{array}{l}\text { the least solvent generation } \\
\text { (due to their age - most are still } \\
\text { students); want to avoid debts } \\
\text { and evaluate the accounts or } \\
\text { services that help in this matter; } \\
\text { debit cards take first place among } \\
\text { priorities, followed by mobile } \\
\text { banking; looking for easy ways to } \\
\text { make money }\end{array}$ \\
\hline $\begin{array}{l}\text { ते } \\
\text { ज्ञ } \\
\text { ' }\end{array}$ & $\begin{array}{l}\text { security is paramount } \\
\text { for them, and they feel } \\
\text { vulnerable because the } \\
\text { Internet is an "open space" } \\
\text { without borders and } \\
\text { boundaries, }\end{array}$ & $\begin{array}{l}\text { increased requirements for } \\
\text { online security both when } \\
\text { making purchases and when } \\
\text { ordering services; one in } \\
\text { three does not trust any } \\
\text { social network }\end{array}$ & $\begin{array}{c}\text { trust the advice and } \\
\text { recommendations of } \\
\text { bloggers and regular Internet } \\
\text { users; use a sophisticated } \\
\text { security system to protect } \\
\text { the Internet }\end{array}$ & $\begin{array}{c}\text { need media literacy training } \\
\text { and information security } \\
\text { development }\end{array}$ \\
\hline
\end{tabular}


(End of Table 3)

\begin{tabular}{|c|c|c|c|c|}
\hline & \multicolumn{4}{|c|}{ Generation type } \\
\hline & $\begin{array}{l}\text { baby boomers } \\
(1946-1964)\end{array}$ & $\begin{array}{c}X \\
(1965-1979 / 80)\end{array}$ & $\begin{array}{c}\text { Y, millennials } \\
(1981-1994 / 6)\end{array}$ & $\begin{array}{c}\text { Z, buzzers } \\
(1997-2012 / 15)\end{array}$ \\
\hline 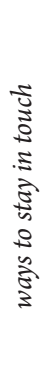 & $\begin{array}{l}\text { traditional printed cards, } \\
\text { discount coupons, loyalty } \\
\text { cards, phone calls, e-mail, } \\
\text { SMS }\end{array}$ & $\begin{array}{l}\text { subscription with company } \\
\text { history; Internet forums; } \\
\text { sending useful materials; } \\
\text { email with thanks after } \\
\text { purchase; personal } \\
\text { discounts that emphasize the } \\
\text { uniqueness of the client and } \\
\text { a special attitude to him }\end{array}$ & $\begin{array}{l}\text { omnichannel: meet on } \\
\text { online platforms or social } \\
\text { networks and create close } \\
\text { links between different } \\
\text { channels; the buyer must } \\
\text { revolve around the brand } \\
\text { ecosystem so that each } \\
\text { communication channel } \\
\text { interacts harmoniously with } \\
\text { others, increasing sales }\end{array}$ & $\begin{array}{l}\text { interact with brands on social } \\
\text { networks and advertising }\end{array}$ \\
\hline$\frac{\vec{\Xi}}{\stackrel{\Xi}{\sigma}}$ & $\begin{array}{l}\text { formation of a stable and } \\
\text { stable group of supporters of } \\
\text { a certain company or product }\end{array}$ & $\begin{array}{l}\text { brand formation and its } \\
\text { positioning in the market }\end{array}$ & $\begin{array}{l}\text { convert regular Internet } \\
\text { users to online shoppers on } \\
\text { any communication channel }\end{array}$ & $\begin{array}{l}\text { consumer behaviour of their } \\
\text { older relatives, because parents, } \\
\text { grandparents trust the opinion } \\
\text { of the buzzers, and give them the } \\
\text { final choice }\end{array}$ \\
\hline
\end{tabular}

Source: development of author

of e-commerce into human life and the "rooting" of streaming content on online platforms.

Thus, in particular, generations $\mathrm{Y}$ and $\mathrm{Z}$ are now mostly focused on the use of all available technical innovations, benefits of e-commerce and this is what distinguishes baby boomers and generation $\mathrm{X}$, most of whom still prefer to shop offline and consume traditional media and advertising (television, newspapers, radio, etc.).

The groups of people listed in Table 3 are not only culturally different, they are now at different stages of financial life. If the young generation $\mathrm{Z}$ is just beginning to form its purchasing power, then the representatives of baby boomers have a fairly broad financial history (KASASA, 2021). The contrast between priorities, values, needs and interests of these generations is sharp.

Knowledge of the characteristics of these generations and their differences in stereotypes, behaviour, views on the present and the future is important for further understanding of the impact of mega trends on our lives. Of course, the division of groups of people into generations is not something stable, the age range is quickly complicated, adjusted, and, accordingly, requires review and marketing tactics of e-commerce, which is aimed at mass online buyers.

The data in Table 3 show that the younger generations often contribute today to the adoption and use of modern technologies by older people, and this is largely true. The speed with which baby boomers are expanding the use of Internet technology is accelerating significantly. Thus, in 2019, 68\% of baby boomers owned a smartphone, while in 2011 there were only 25\% (Gomonova, 2021).

\section{The impact of digital transformation on customer preferences}

Knowledge of trends and priorities of different generations is now important because it allows you to easily identify the preferences of e-commerce participants and project their future behaviour. Understanding the differences between these age groups allows you to choose effective marketing tools because the segmentation of target audience in one way or another includes age as one of the factors.

The generations of people studied have different financial histories and have their own "financial fears". Each generation earns and saves for different stages of life - retirement, university, car purchase and more. These generations of people grew up in the developing technological world, but each age group has its own unique preferences for financial relations management (Holoborodko \& Kraus, 2018). All studied generations of people were formed in different financial climates with their own financial positions. However, the COVID-19 pandemic was a great equalizer, as all generations had to adapt to a new way of working and living.

Thus, in particular, people's banking behaviour is changing. According to a recent study by Adobe Analytics, $44 \%$ of generation $\mathrm{Z}$ people and $31 \%$ of millennials use bank chatbots to answer their questions and believe that such a communication experience is even better than talking to a real person (KASASA, 2021). However, for more complex banking tasks, even the younger generation prefers to get additional help from a bank employee.

Modern digital technologies, which are the basis of e-commerce, have long ceased to affect only the younger 
generations. Each succeeding generation more easily masters the services of digital and mobile banking, and more. But the COVID-19 pandemic has led to a new wave of "latecomers" who are now actively "banking" in digital format. Of course, only time will tell how long the full transition to digital tools and services will last, but the positive digital experience already gained today will expand the probability of total digital coverage of all generations (Manzhura \& Kraus, 2019).

As world's major e-commerce players improve their sales methods, small retailers also have to take into account a number of current trends. Accordingly, in 2019, only 6 out of 10 baby boomers in the USA bought products online, but the younger buyers, the higher percentage. Almost $85 \%$ of millennials by goods online, they increase their purchasing power, and hence their influence every year. More than 60\% of generation $\mathrm{Z}$ consumers choose a brand that offers options for buying online and receiving goods in store. Generations of baby boomers shop online much less often than generation $\mathrm{Z}$ and millennials. At the same time, the female part of the Internet audience aged 55-64 is more likely to make online purchases than men aged 16-24. Young people are more likely to use mobile phones for online shopping, while most baby boomers shop online from computer.

Paula Hansen, Director of Revenue Management at SAP Customer Experience, states that "the future success of a brand will depend on how exceptional the shopping experience it can offer to each generation. It is necessary to adapt marketing activities taking into account the age of consumers and the best way of shopping - this will help develop the necessary flexibility to overcome possible crises in the future and more actively recover from a coronavirus pandemic" (RAU, 2021).

Representatives of different generations in their own way perceive modern digital transformations and the rapid and dynamic development of digital technologies, which have already entered the life of society. For buzzers, these are all everyday phenomena and habitual processes, they easily accept changes and adapt to them. However, for baby boomer generation, realizing the need to engage in digital transformation takes time and considerable effort. Preferences and behaviour as online consumers, in terms of generations, we presented in Table 4.

Consumers from generation $\mathrm{Z}$, which are 18-24 years old today, form and develop their professional competencies and abilities, gain their first professional experience and enter the active phase of work. Buzzers are active, digital (Digital Native), they cannot imagine their lives without information technology and the global Internet; because they set most of the current trends, it is not surprising that business structures in their activities are forced to focus on the peculiarities of their education (distance learning, education on online platforms such as MOOC and Coursera, learn quickly and prefer to gain practical experience as opposed to gaining university knowledge, compensate for the lack of experience with implemented projects), involvement

Table 4

Preferences and behaviour as online consumers, representatives of generations of baby boomers, X, Y, Z

\begin{tabular}{|c|c|c|c|c|}
\hline \multirow{2}{*}{$\begin{array}{l}\text { Preferences for online } \\
\text { shopping }\end{array}$} & \multicolumn{4}{|c|}{ Generation } \\
\hline & baby boomers & $X$ & $\mathrm{y}$, millennials & Z, buzzers \\
\hline priority in online shopping & $\begin{array}{l}\text { convenience, price, } \\
\text { free shipping, brand } \\
\text { reputation }\end{array}$ & $\begin{array}{c}\text { convenience, loyalty } \\
\text { reward or discount, ease } \\
\text { of return }\end{array}$ & $\begin{array}{c}\text { convenience, free } \\
\text { shipping, site experience, }\end{array}$ & $\begin{array}{c}\text { price, speed, convenience, } \\
\text { free shipping }\end{array}$ \\
\hline buy most often & $\begin{array}{l}\text { offline store, online brand } \\
\text { store, a physical store }\end{array}$ & $\begin{array}{l}\text { Facebook, a physical store } \\
\text { and an online brand store }\end{array}$ & $\begin{array}{l}\text { Facebook, Instagram, } \\
\text { Snapchat, eBay }\end{array}$ & $\begin{array}{c}\text { Instagram, Snapchat, eBay, } \\
\text { Amazon }\end{array}$ \\
\hline $\begin{array}{l}\text { main reason why buys } \\
\text { online and not offline }\end{array}$ & $\begin{array}{l}\text { ability to touch or try on } \\
\text { the item, ability to ensure } \\
\text { the item does not have } \\
\text { any defects }\end{array}$ & $\begin{array}{l}\text { ability to touch or try on } \\
\text { the item, convenience }\end{array}$ & speed, accessibility & price, convenience \\
\hline $\begin{array}{c}\text { key reason for } \\
\text { dissatisfaction with online } \\
\text { shopping }\end{array}$ & product being out of stock & paying shipping costs & difficult return process & waiting for the product \\
\hline $\begin{array}{l}\text { payment system for online } \\
\text { shopping }\end{array}$ & credit card & $\begin{array}{c}\text { financing (Buy now, pay } \\
\text { later) }\end{array}$ & PayPal & Mobile Wallet \\
\hline $\begin{array}{l}\text { \% goods purchased online } \\
\text { that are returned }\end{array}$ & $37 \%$ & $45 \%$ & $50 \%$ & $75 \%$ \\
\hline tracked information & $\begin{array}{l}\text { salary range, relationship } \\
\text { status }\end{array}$ & parental status, profession & $\begin{array}{l}\text { personal preferences, } \\
\text { phone number }\end{array}$ & email, browsing history \\
\hline $\begin{array}{c}\text { what can be offered to get } \\
\text { more information }\end{array}$ & $\begin{array}{c}\text { none, they are not } \\
\text { interested }\end{array}$ & $\begin{array}{l}\text { VIP membership, early } \\
\text { access to new products }\end{array}$ & $\begin{array}{c}\text { faster delivery, free } \\
\text { shipping }\end{array}$ & $\begin{array}{l}\text { personalization, product } \\
\text { discount }\end{array}$ \\
\hline
\end{tabular}

Source: development of author 
in work (remote work, freelance, entrepreneurial ambitions, are "universal soldiers" in the workplace, are not tied to the workplace or to fixed working hours), consumption (active consumers of online video, ethical consumption), communications (advanced, progressive, digital; use new online tools as easily as they lose concentration), business management (positive motivation, optimism, the ability to present their own business ideas and be able to implement them, the tendency to rethink corporate values such as sustainability and gender equality, open communication in the team, they are attracted by great influence - big projects - big ideas - big profits).

The generation of buzzers "lives", cannot sit still for a long time, seeks globalization and become part of big business, then start their own business and change the world for the better. The best that previous generations can do for buzzers is to support them, believe in them, and give them the opportunity to be themselves.

Given the above, it is not surprising that not only changes the person with his views and preferences, but also changes the philosophy of doing business developing leadership skills, self-management of the organization, marketing technology.

\section{Conclusions}

As a result, it is worth noting that today the world is changing so rapidly and dynamically that it cannot but affect the trade, which is increasingly becoming "online" in the e-commerce sector. Being able to shop anywhere, anytime is main reason why people of all generations choose online shopping. Therefore, in the near future, commercial success will directly depend on how exceptional the buying experience can be offered by the seller for each generation. It is necessary to adapt marketing activities taking into account the age of consumers and the best way of shopping, because it will help develop the necessary flexibility to overcome possible crises in the future.

We are witnessing various consequences of digital transformation in business models. For example, digital technologies make it possible to reorient the boundaries of firms to more global levels. Common digital business models tend to lead to a higher level of interaction between different participants. Such enterprises tend to compete on a larger scale than traditional enterprises due to low geographical boundaries and the need for resources to satisfy customers. As search and communication costs have dropped significantly, operating costs are generally much lower than for traditional businesses. Internet technologies have increased competition, reduced barriers to entry, led to more substitutes, and increased consumer power. Consequently, profit opportunities have decreased in most industries. As a result, digital business structures stimulate the economic development of an environment that is often characterized by dynamic competition and high consumer surpluses.

We believe that key areas of strategic transformation for the future should be:

- Customer Centricity. Omni-channel, analytics, variable, scoring, adaptability and forecasting tools should be introduced to find the consumer. This will adequately respond to market changes. Today, the client is where he will be provided with a product or service in a timely, convenient, comfortable and fast manner.

- Value. The way of consuming services is changing - from banking and retail to the Internet of Things. It becomes fundamentally important for client to buy products and services fully and remotely, to receive operational support around the clock and without visiting offices.

- Data Governance. Definition and household management system of value proposals. Based on the data, customer behaviour is modelled, demand is predicted, benefits are formed and even products and services are adapted.

- R\&D. Transition to the model of constant experimentation. If earlier the product was the result of extensive preliminary marketing research and expert wording, today the possibilities of digital technologies and the speed of change in the markets force businesses to constantly test and test their solutions.

Further research should focus on in-depth study of digital transformation of business operations, improving customer service, to study innovative digital tools in order to find new business opportunities based on this knowledge.

\section{References:}

Issaacson, W. (2017). Innovatory: yak hrupa khakeriv, heniiv ta hikiv zdiisnyla tsyfrovu revoliutsiiu [Innovators: as a group of hackers, geniuses and geeks made a digital revolution]. Kyiv: Nash format. (in Ukrainian)

Andrusiak, N. O., Kraus, N. M., \& Kraus, K. M. (2020). Digital Cubic Space as a New Economic Augmented Reality. Sci. innov., vol. 16, no. 3: 92-105. https://doi.org/10.15407/scine16.03.092

Azzam, M., Sami, N., \& Khalil, T. (2020). Egypt X.0? Moving behind Industry 4.0 towards Industry X.0 Towards the Digital World and Industry X.0. Proceedings of the 29th International Conference of the International Association for Management of Technology, IAMOT 2020, pp. 103-117. Available at: https://www.scopus.com/inward/record. uri? eid=2-s2.0-85092635745\&partnerID=40\&md5=b617deaa3f8f46ae4417254d1a784d50 (accessed $15 \mathrm{March}$ 2021). 
KASASA (2021). Boomers, Gen X, Gen Y, and Gen Z. Available at: https://www.kasasa.com/articles/generations/ gen-x-gen-y-gen-z (accessed 15 March 2021).

Chechin, O. P. (2014). Mekhanizm formirovaniia strategii promyshlennogo predpriiatiia [The mechanism of forming a strategy for the development of an industrial enterprise]. Vestnik Samarskogo gosudarstvennogo tekhnicheskogo universiteta. Seriia: Ekonomicheskie nauki [Bulletin of the Samara State Technical University. Series: Economic Sciences], 1(11): 46-49. (in Russian)

Chernykh, E. A. (2008). Novye tekhnologii, innovatcii i uspekh biznesa [New technologies, innovation and business success]. Menedzhment kachestva [Quality management], 1:60-71. (in Russian)

Chmeruk, H. H., Kralich, V. R., \& Burlakova, I. A. (2018). Deiaki aspekty tsyfrovoi transformatsii pidpryiemstv [Some aspects of digital transformation of enterprises]. Prychornomorski ekonomichni studii [Black Sea Economic Studies], vol. 34: 97-101. (in Ukrainian)

Kraus, N. M., Goloborodko, O. P., \& Krays K. M. (2018). Tsyfrova ekonomika: trendy ta perspektyvy avanhardnoho kharakteru rozvytku [Digital economy: trends and prospects for the avant-garde character of the development]. Effective economy, no. 1, (electronic journal). Available at: http://www.economy.nayka.com.ua/pdf/1_2018/8.pdf (accessed 5 November 2019). (in Ukrainian)

Gomonova, D. (2021). Zummery, millenialy, pokolenie X ili bumery: sliianie pokolenii na eCommerce [Buzzers, Millennials, Gen X or Boomers: Generational Impact on eCommerce]. Serpstat. Available at: https://serpstat.com/ru/blog/vliyanie-pokolenij-na-ecommerce/ (accessed 14 March 2021). (in Russian)

Grybanov, Yu. I., \& Rudenko, M. N. (2020). Tcifrovaia transformatciia biznesa [Digital business transformation]. Moscow: Dashkov and Co. (in Russian)

Kraus, N., Kraus, K., \& Marchenko, O. (2020). Vplyv servizatsii na rezultaty tsyfrovoi ekonomichnoi pidpryiemnytskoi diialnosti [The impact of servation on the results of economic digital entrepreneurship activities]. Ukraina $v$ konteksti hlobalnykh ta natsionalnykh suchasnykh servizatsiinykh protsesiv $i$ tsyfrovoi ekonomiky [Ukraine in the context of global and national modern servisation processes and digital economy]: monograph. Praha: OKTAN PRINT, pp. 81-91. https:// doi.org/10.46489/UITCOG0909 (in Ukrainian)

Kraus, N. M. (2019). Innovatsiina ekonomika v hlobalnomu sviti: instytutsiinyi bazys formuvannia $i$ traiektoriia rozvytku [Innovative economy in a globalized world: institutional basis of formation and development trajectory]. Kyiv: Agrar Media Group. (in Ukrainian)

Kraus, N. M., \& Kraus, K. M. (2018). Suchasni informatsiini ta innovatsiini tekhnolohii u sferi finansiv, upravlinnia ta administruvannia [Modern digital information and innovation technologies in the field of finance, management and administration]. Ekonomichna stratehiia ta polityka realizatsii yevropeiskoho vektora rozvytky Ukrainy: kontseptuvalni zasady, vyklyky ta protyrichchia [Economic strategy and policy of realization of European vector of development of Ukraine: conceptual bases, challenges and contradictions]: monograph. Kyiv: Taras Shevchenko National University of Kyiv; VAT “Center for Economic Research"; SIC GROUP UKRAINE LLC, pp. 469-487. (in Ukrainian)

Kraus, N. M., \& Kraus, K. M. (2018). Yaki zminy nese Industriia 4.0 dlia ekonomiky ta vyrobnytstva? [What changes does Industry 4.0 bring to the economy and manufacturing?]. Formuvannia rynkovykh vidnosyn $v$ Ukraini [Formation of market relations in Ukraine], 9(208): 128-136. (in Ukrainian)

Makarov, A. Yu., \& Makarov, A. A. (2010). Tcifrovaia ekonomika. Tekhnologii meniaiut menedzhment. Praktika vnedreniia i rezultaty [Digital economy. Technology is changing management. Implementation practice and results]. Moscow: SOLON-Press. (in Russian)

Manzhura, O. V., Kraus, N. M., \& Kraus, K. M. (2019). Profesii maibytnoho u virtualnii realnosti innovatsiinotsyfrovoi sfery [The professions of the future in the virtual reality of the innovation-digital space]. BIZNES INFORM [BUSINESS INFORM], 1: pp. 132-138. (in Ukrainian)

Manzhura, O. V., Kraus, N. M., \& Kraus, K. M. (2020). Ekonomichna profesiina osvita pokolinnia tsyfrovykh liudei $\mathrm{v}$ umovakh funktsionuvannia innovatsiino-pidpryiemnytskykh universytetiv [Economic professional education of the generation of digital people in the conditions of functioning of innovative and entrepreneurial universities]. BIZNES INFORM [BUSINESS INFORM], 3: 182-191. Available at: https://www.business-inform.net/ article/?year=2020\&abstract=2020_3_0_182_191 (accessed 07 January 2021). DOI: 10.32983/2222-44592020-3-182-191 (in Ukrainian)

Marchenko, O., Kraus, N., \& Kraus, K. (2020). Innovatsiine pidpryiemnytstvo ta tsyfrovyi bizness: naukovi ta ekonomichni osoblyvosti rozbytku ta zminy $\mathrm{v}$ upravlinni [Innovative entrepreneurship and digital business: scientific and economic features of development and changes in management]. Efectyvna ekonomika [Effective economy], no. 4, (electronic journal). Available at: http://www.economy.nayka.com.ua/?op=1\&z=7779 (accessed 10 January 2021). DOI: 10.32702/2307-2105-2020.4.8 (in Ukrainian)

Nechepurenko, M. N. (2006). Problemy ekonomichnoho rozvytku pidpryiemstv [Problems of economic development of enterprises]. Pytannia ekonomichnykh nauk [Questions of economic sciences], 1(17): 23-25. (in Ukrainian)

Ouchi, W. (1981). Theory "Z": How American business can meet the Japanese challenge. Reading, MA: AddisonWesley.

Pohorielov, Yu. S. (2012). Rozvytok pidpryiemstva: poniattia ta vydy [Enterprise development: concepts and types]. Available at: http://www.nbuv.gov.ua/Articles/Kultnar/knp88/knp88_75-81.pdf (accessed 14 March 2021). (in Ukrainian) 
Vol. 7 No. 2, 2021

Prokhorov, A. V., \& Konik, L. D. (2018). Tcifrovaia transformatciia: analiz, trendy, mirovoi opyt [Digital transformation: analysis, trends, global experience]. Moscow: Ridero. (in Russian)

SAP research: how customer habits are changing as the economy recovers (2021). RAU. Available at: https://rau.ua/novyni/sap-zvychky-pokuptsiv/ (accessed 20 March 2021).

Shantarenkova, M. (2017). Notatky pro tsyfrove pidpryiemstvo. Industriia X.0 - "aitizatsiia" neskinchenna! [Notes on digital business. Industry X.0 - "ITization" is endless!]. Part 2 (12 December 2017). Available at: https://upr.ru/article/zametki-o-cifrovom-predpriyatii-chast-2-industriya-h-0-ajtizaciya-beskonechna/ (accessed 21 March 2021). (in Ukrainian)

Shvab, K. (2017). Chetvertaia promyshlennaia revoliutciia [Fourth industrial revolution]. Moscow: E. (in Russian) Tapscott, D. (1995). The Digital Economy: Promise and Peril in the Age of Networked Intelligence. McGraw-Hill.

Teece, D., Pisano, G., \& Shuen, A. (2003). Dinamicheskie sposobnosti firmy I strategicheskoe upravlenie [Firm dynamic capabilities and strategic management]. Vestnik Sankt-Peterburskogo universiteta [Bulletin of St. Petersburg. university], vol. 4: 133-185. (in Russian)

Torado, M. P. (1997). Ekonomicheskoe razvitie [Economic development]. Moscow: UNITY. (in Russian)

What is Discovery Commerce? (2021). Facebook. Available at: https://www.facebook.com/business/c/discoverycommerce (accessed 9 March 2021).

What will be the e-commerce of the new era? (2020). Adindex. Available at: https://adindex.ru/publication/ opinion/internet/2020/10/28/286400.phtml (accessed 25 March 2021). 